\title{
ANALISIS FAKTOR-FAKTOR YANG MEMPENGARUHI KUALITAS LAPORAN KEUANGAN PEMERINTAH
}

\author{
Ramdany $^{1}$, Yusuf Setiawan ${ }^{2}$ \\ 1,2STIE Muhammadiyah Jakarta, ramdany2012@gmail.com; yusup.setiawan@gmail.com
}

\begin{abstract}
ABSTRAK
Penelitian ini bertujuan untuk mengetahui pengaruh Sistem Aplikasi Keuangan Tingkat Instansi (SAKTI), kompetensi Sumber Daya Manusia (SDM), Pengendalian Internal (PI) terhadap Kualitas Laporan Keuangan Pemerintah (KLKP). Penelitian ini menggunakan pendekatan kuantitatif. Data dikumpulkan melalui kuesioner dari 92 responden operator aplikasi SAKTI pada satuan kerja Direktorat Jenderal Perbendaharaan, Kementerian Keuangan. Analisis data mengunakan SmartPLS. Hasil penelitian menunjukkan bahwa implementasi SAKTI dan PI berpengaruh signifikan terhadap KLKP, sedangkan kompetensi SDM tidak berpengaruh terhadap KLKP. Penelitian ini terbatas dilakukan dilingkungan satuan kerja Direktorat Jenderal Perbendaharaan di pulau Jawa.

Kata Kunci : Implementasi SAKTI, Kompetensi Sumber Daya Manusia, Pengendalian Internal, Kualitas Laporan Keuangan Pemerintah

ABSTRACT

The study aims to determine the effect of the Agency Level Financial Application System (SAKTI), the competence of Human Resources (SDM), Internal Control (PI) on the Quality of Government Financial Reports (KLKP). This study uses a quantitative approach. Data was collected through questionnaires from 92 respondents to the SAKTI application operator at the Directorate General of Treasury's work unit, Ministry of Finance. Data analysis using SmartPLS. The results showed that the implementation of SAKTI and PI had a significant effect on KLKP, while SDM competencies had no effect on KLKP. This research is limited to conduct within the work unit of the Directorate General of Treasury on the island of Java.
\end{abstract}

Keywords: Implementation of SAKTI, Human Resource Competence, Internal Control, Quality of Government Financial Reports

Naskah diterima : 22-04-2021, Naskah dipublikasikan : 30-04-2021

\section{PENDAHULUAN}

Badan Pemeriksa Keuangan (BPK) menetapkan peringkat opini Wajar Tanpa Pengecualian (WTP) atas Laporan Keuangan Pemerintah Pusat (LKPP) Tahun Anggaran 2016, 2017, dan 2018. Opini tersebut ditetapkan berdasarkan pertimbangan aspek kesesuaian dengan Standar Akuntansi Pemerintah (SAP), kecukupan pengungkapan sesuai SAP, kepatuhan terhadap peraturan perundang-undangan, dan efektivitas sistem pengendalian internal (BPK, 2018).

Hasil pemeriksaan BPK terhadap LKPP tahun 2018 terdapat 25 temuan meskipun tidak material mempengaruhi kewajaran laporan keuangan Jumlah temuan ini meningkat dibandingkan pada tahun 2017, 2016 dan 2015. Walaupun Laporan Keuangan Pemerintah tahun 2015 dan 2014 mendapat peringkat Wajar Dengan Pengecualian (WDP). Perkembangan opini dan jumlah temuan LKPP dari periode tahun 2014 - 2018 dapat dijelaskan dalam tabel dibawah ini.

Tabel 1. Opini dan Temuan LKPP Tahun 2014 - 2018

\begin{tabular}{ccc}
\hline Periode LKPP & Opini & Jumlah Temuan \\
\hline 2014 & Wajar Dengan Pengecualian (WDP) & 30 \\
2015 & Wajar Dengan Pengecualian (WDP) & 22 \\
2016 & Wajar Tanpa Pengecualian (WTP) & 16
\end{tabular}




\begin{tabular}{ccc}
\hline & & \\
\hline Periode LKPP & Opini & Jumlah Temuan \\
\hline 2017 & Wajar Tanpa Pengecualian (WTP) & 18 \\
2018 & Wajar Tanpa Pengecualian (WTP) & 25 \\
\hline
\end{tabular}

Sumber : BPK RI (2019)

Salah satu rekomendasi BPK dalam pemeriksaan LKPP Tahun 2016 adalah perbaikan integrasi sistem informasi penyusunan laporan keuangan pemerintah. Menindaklanjuti rekomendasi tersebut Kementerian Keuangan, melalui Direktorat Sistem Informasi dan Teknologi Perbendaharaan (SITP) mengembangkan sistem aplikasi terintegrasi untuk mendukung proses pembuatan laporan keuangan yang berkualitas yang dikenal dengan Sistem Aplikasi Keuangan Tingkat Instansi (SAKTI).

Aplikasi SAKTI mencakup seluruh proses pengelolaan keuangan negara pada satuan kerja dimulai dari proses penganggaran, pelaksanaan, sampai dengan pelaporan keuangan. SAKTI mulai dirintis sejak tahun 2015 untuk Satuan Kerja (Satker) di lingkup Ditjen Perbendaharaan, Kementerian Keuangan sebagai pilot project.

Laporan keuangan Kementerian Keuangan tahun 2018 mendapatkan opini WTP. Namun dalam proses pembuatan laporan keuangan masih terdapat kendala ketidakstabilan SAKTI. Ketidakstabilan SAKTI terjadi salah satunya karena proses pengembangan SAKTI dilakukan waktu yang relatif pendek. Pada proses pengembangan sistem yang pendek ini terdapat beberapa kondisi yang perlu diperbaiki untuk menyesuaikan dengan kebutuhan lapangan. Sejak aplikasi SAKTI dilaunching tahun 2015-2018 sudah dilakukan perbaikan dan pembaharuan (update) sebanyak 34 kali (SITP, 2020).

Penelitian tentang pengaruh sistem aplikasi informasi akuntansi terhadap kualitas laporan keuangan menghasilkan berbagai pendapat. Penggunaan aplikasi sistem informasi akuntansi berpengaruh positif terhadap kualitas laporan keuangan (Salehi dan Torabi, 2012; Nurillah, 2014; Ramadan, 2015; Sagara, 2015; Anwar dan Mukadarul, 2016; Rahman dan Fachri, 2016; Synthia, 2016; Lubis, 2017; Anggadini, 2018; Mardinan et.al.,2018; Muda et.al., 2018; Romanti, 2018; Dewi dan Yadnyana, 2019; Hapsari et.al., 2019; Ratmono, 2019; Samosir dan Setiyawati, 2019; Wibowo dan Darmanto, 2019). Namun hasil penelitian yang dilakukan oleh Nurlis dan Yadiati (2017), Setyawan (2018), Mulyadi dan Haryoso (2019) menyatakan aplikasi informasi akuntansi tidak berpengaruh terhadap kualitas laporan keuangan.

Selain penggunaan aplikasi sistem informasi, faktor lain yang mempengaruhi kualitas laporan keuangan adalah kompetensi Sumber Daya Manusia (SDM). Kompetensi SDM merupakan salah satu faktor menentukan keberhasilan kinerja organisasi (BPKP, 2015). Kompetensi SDM merupakan faktor yang mempengaruhi kualitas laporan keuangan (Nurillah, 2014). Kompetensi SDM yang tinggi akan menghasilkan laporan keuangan yang berkualitas (Setyowati, 2016). Masalah SDM yang sering muncul adalah ketidaksiapan SDM dalam mengoperasikan aplikasi SAKTI. Keberadaan SAKTI menuntut pengguna agar lebih detail dalam menginput data, tidak menunda pekerjaan dan dapat bersinergi dengan pengguna lainnya. Hasil training pelaporan keuangan yang diselenggarakan oleh Direktorat Sistem Informasi dan Teknologi Perbendaharaan (SITP) mengindikasikan terdapat kesenjangan kompetensi SDM dalam mengaplikasikan SAKTI (SITP, 2015). Rekapitulasi jumlah aduan ke helpdesk terkait aplikasi SAKTI tahun 2018 disajikan dalam tabel dibawah ini.

Tabel 2. Aduan Aplikasi SAKTI

\begin{tabular}{cccccc}
\hline $\begin{array}{c}\text { Kelompok } \\
\text { (Stream) }\end{array}$ & OK & Warning & Fail & Total & Capaian \\
\cline { 2 - 4 } & & 8 & 4 & 2194 & \\
\hline Administrasi & 2182 & 14 & 9 & 474 & $99.82 \%$ \\
Pelaksanaan & 451 & 14 & 19 & 517 & $98.1 \%$ \\
Pelaporan & 484 & & & & \\
\hline
\end{tabular}

Sumber : HAI DJPb (2019) 
Penelitian mengenai pengaruh kompetensi sumber daya manusia terhadap kualitas laporan keuangan menghasilkan variasi. Hasil penelitian menunjukkan kompetensi sumber daya manusia memiliki pengaruh positif terhadap kualitas laporan keuangan (Nurillah, 2014; Ramadan, 2015; Sagara, 2015; Anwar dan Mukadarul, 2016; Simon et.al., 2016; Synthia, 2016; Heksarini dan Nadir, 2017; Lubis, 2017; Nurlis dan Yadiati, 2017; Mardinan et.al., 2018; Muthaher, 2018; Novyarni dan Aprileny, 2018; Romanti, 2018; Dewi dan Yadnyana, 2019; Hapsari et.al., 2019; Ratmono, 2019; Samosir dan Setiyawati, 2019). Sedangkan penelitian yang dilakukan oleh Desipradani dan Nuraini (2018), Setyawan (2018), Utaminingtyas (2019) menghasilkan SDM berpengaruh negative terhadap kualitas laporan keuangan.

Pengendalian internal merupakan faktor yang mempengaruhi kualitas laporan keuangan (Wadiyo, 2019). Pengendalian internal merupakan salah satu aspek penilaian BPK dalam menerbitkan opini. BPK menemukan 19 kelemahan pengendalian internal pada LKPP tahun 2018. Jumlah temuan kelemahan pengendalian internal meningkat dibandingkan pada tahun 2017 dan 2016. Jumlah kelemahan pengendalian internal pada LKPP tahun 2014 dan 2015 relatif lebih banyak saat saat opini Wajar Dengan Pengecualian (WDP). Temuan kelemahan pengendalian internal LKPP periode tahun 2014-2018 disajikan dalam tabel dibawah ini.

Tabel 3.Temuan Kelemahan Pengendalian Internal LKPP Tahun $2014-2018$

\begin{tabular}{ccc}
\hline Periode LKPP & Opini & Jumlah Kelemahan \\
\hline 2014 & Wajar Dengan Pengecualian (WDP) & 21 \\
2015 & Wajar Dengan Pengecualian (WDP) & 14 \\
2016 & Wajar Tanpa Pengecualian (WTP) & 12 \\
2017 & Wajar Tanpa Pengecualian (WTP) & 13 \\
2018 & Wajar Tanpa Pengecualian (WTP) & 19 \\
\hline
\end{tabular}

Sumber : BPK RI (2019)

Pengendalian internal memiliki pengaruh positif terhadap kualitas laporan keuangan (Nurillah, 2014; Ramadan, 2015; Anwar dan Mukadarul, 2016; Samriraay, 2016; Heksarini dan Nadir, 2017; Kewo dan Afiah, 2017; Lubis, 2017; Mardinan et.al., 2018; Muda et.al., 2018; Muthaher, 2018; Romanti, 2018; Dewi dan Yadnyana, 2019; Mulyadi dan Haryoso, 2019; Ratmono, 2019; Samosir dan Setiyawati, 2019; Utaminingtyas, 2019; Wibowo dan Darmanto, 2019). Namun penelitian yang dilakukan oleh Simon et.al. (2016), Nurlis dan Yadiati (2017), Desipradani dan Nuraini (2018) menyimpulkan bahwa sistem pengendalian intern berpengaruh negatif terhadap kualitas laporan keuangan.

\section{KAJIAN LITERATUR}

\section{New Public Management Theory (Teori NPM)}

Salah satu gerakan reformasi sektor publik adalah dengan munculnya konsep New Public Management (Febriyanto, 2012). Istilah New Public Management (NPM) dikenalkan oleh Christoper Hood (1991). NPM merupakan paradigma alternatif yang menekankan perubahan perilaku aparatur Pemerintah menjadi lebih efisien dan efektif. Karakterisitik dalam NPM lebih berfokus pada manajemen bukan kebijakan, standar dan ukuran kinerja yang jelas, control hasil, pembagian tugas, persaingan di sektor publik, gaya manajemen, serta kedisiplinan dan tidak boros dalam menggunakan sumber daya (Hood, 1991). Akuntansi akrual merupakan bentuk sistem manajemen sektor privat yang diadopsi ke sektor publik sebagai alat pengukuran kinerja (Likierman, 2003; Prabowo, 2017 ).

\section{Laporan Keuangan Pemerintah}

Peraturan Pemerintah Nomor 71 Tahun 2010 mengatur perubahan basis Standar Akuntansi Pemerintah (SAP) dari kas basis menjadi akrual. SAP Berbasis akrual diterapkan dalam menyusun dan 
menyajikan laporan keuangan pemerintah. Pendapatan, beban, aset, utang, dan ekuitas dalam pelaporan finansial dilaporkan berbasis akrual.

Pelaporan keuangan pemerintah bertujuan menyajikan informasi yang bermanfaat bagi para pengguna dalam menilai akuntabilitas dan membuat keputusan baik keputusan ekonomi, sosial, maupun politik (Mardiasmo, 2009). Laporan keuangan digunakan untuk mengetahui nilai sumber daya ekonomi yang dimanfaatkan untuk melaksanakan kegiatan operasional pemerintahan, menilai kondisi keuangan, mengevaluasi efektivitas dan efisiensi suatu entitas pelaporan, dan membantu menentukan ketaatannya terhadap peraturan perundang-undangan. Laporan keuangan Pemerintah terdiri dari Laporan Realisasi Anggaran (LRA), Laporan Perubahan Saldo Anggaran Lebih (LPSAL), Neraca, Laporan Operasional (LO), Laporan Arus Kas (LAK), Laporan Perubahan Ekuitas (LPE), dan Catatan atas Laporan Keuangan (CaLK).

\section{Sistem Informasi Akuntansi}

Sistem informasi akuntansi adalah sistem informasi yang digunakan untuk mengumpulkan, mencatat, menyimpan dan mengelola data untuk menghasilkan suatu informasi untuk mengambil keputusan (.Romney dan Steinbart, 2015). Sistem informasi akuntansi adalah organisasir formulir, catatan dan laporan yang dikoordinasir sedemikian rupa untuk menyediakan informasi keuangan yang dibutuhkan oleh manajemen dalam pengambilan keputusan (Mulyadi, 2016).

Berdasarkan pendapat diatas dapat disimpulkan bahwa sistem informasi akuntansi adalah sistem informasi yang mengumpulkan, mencatat, menyimpan dan mengelola data untuk menghasilkan informasi keuangan yang berguna bagi manajemen dalam pengambilan keputusan. Sistem informasi akuntansi wajib menyediakan informasi yang diperlukan secara tepat waktu, dapat menjaga keamanan harta dan efisien dalam mengoperasikannya dengan mempertimbangkan biaya dan manfaat (Baridwan, 2010).

\section{Sistem Aplikasi Keuangan Tingkat Instansi (SAKTI)}

Menteri Keuangan menetapkan Peraturan Menteri Keuangan Nomor 270 Tahun 2014 tentang Penerapan Standar Akuntansi Pemerintah Berbasis Akrual Pada Pemerintah Pusat. PMK tersebut menyatakan bahwa penerapan SAP berbasis akrual dilaksanakan menggunakan Sistem Aplikasi Terintegrasi. Sistem Aplikasi Terintegrasi adalah sistem aplikasi terintegrasi seluruh proses yang terkait dengan pengelolaan APBN dimulai dari proses penganggaran, pelaksanaan, dan pelaporan pada Bendahara Umum Negara dan Kementerian Negara/Lembaga. Aplikasi SAKTI dipayungi hukum melalui Peraturan Menteri Keuangan Nomor 223 Tahun 2015 tentang Pelaksanaan Piloting Sistem Aplikasi Keuangan Tingkat Instansi.

Pengguna mengakses aplikasi SAKTI melalui Desktop User Interface dari masing-masing PC atau Laptop yang terhubung dengan WAN. Untuk menjamin bahwa transaksi dalam SAKTI dilakukan oleh pihak yang memiliki otoritas/wewenang, user atau pengguna SAKTI dikelompokkan ke dalam tiga kelompok besar:
a. Operator
b. Validator/checker
c. Approver

Pengguna tersebut memerankan proses pengelolaan keuangan negara dengan diberikan akses pada modul terkait. SAKTI dibagi menjadi beberapa modul yang saling terintegrasi yaitu Modul Administrasi, Modul Penganggaran, Modul Komitmen, Modul Pembayaran, Modul Bendahara, Modul Persediaan, Modul Aset Tetap, Modul General Ledger dan Pelaporan (GLP),

SAKTI memiliki fitur dalam penyusunan laporan keuangan yaitu akuntansi berbasis akrual, terdapat validasi transaksi, periode unaudited dan audited dalam rangka koreksi, laporan komparatif, serta proses rekonsiliasi langsung dengan Bendahara Umum Negara (BUN). 


\section{JURNAL AKUNTANSI, Vol. 10, No. 1, April (2021)}

\section{Kompetensi Sumber Daya Manusia}

Kompetensi adalah "Underlying characteristic's of individual which is causally related to criterion referenced effective and or superior performance in a job or situation" (Spencer, 1993). Dapat dipahami secara umum kompetensi adalah karakteristik yang mendasari seseorang dan berkaitan dengan efektivitas kinerja individu dalam pekerjaannya. Kompetensi adalah sebuah kombinasi antara keterampilan (skill), atribut personal dan pengetahuan (knowledge) yang tercermin melalui perilaku kinerja (job behavior) yang dapat diamati, diukur dan dievaluasi. Kompetensi memiliki lima karakteristik sebagai berikut (Spencer, 1993) adalah knowledge, skills, self concept, traits, motives.

\section{Pengendalian Internal}

Pengendalian intern adalah suatu proses-yang dijalankan oleh dewan komisaris manajemen, dan personel lain entitas yang didesain untuk memberikan keyakinan memadai mengenai pencapaian keandalan pelaporan keuangan, efektivitas dan efisiensi operasi, dan kepatuhan terhadap hukum dan peraturan yang berlaku" (SPAP No.69, 2016). Pengendalian internal dapat diartikan sebagai proses yang integral pada tindakan dan kegiatan yang dilakukan secara terus menerus oleh pimpinan dan seluruh pegawai untuk memberikan keyakinan memadai atas tercapainya tujuan organisasi melalui kegiatan yang efektif dan efisien, keandalan pelaporan keuangan, pengamanan aset negara, dan ketaatan terhadap peraturan perundang-undangan (Peraturan Pemerintah Nomor 60 Tahun 2008).

COSO (2013) menjelaskan ada 5 (lima) komponen pengendalian internal tersebut sebagai berikut:

1. Lingkungan Pengendalian (Control Environment)

2. Penilaian Risiko (Risk Assesment)

3. Aktivitas Pengendalian (Control Activities)

4. Informasi dan Komunikasi (Information and Communication)

5. Aktivitas Pemantauan (Monitoring Activities)

\section{Kerangka Pemikiran}

Kerangka pemikiran dalam penelitian ini dapat digambarkan dalam gambar grafik dibawah ini.

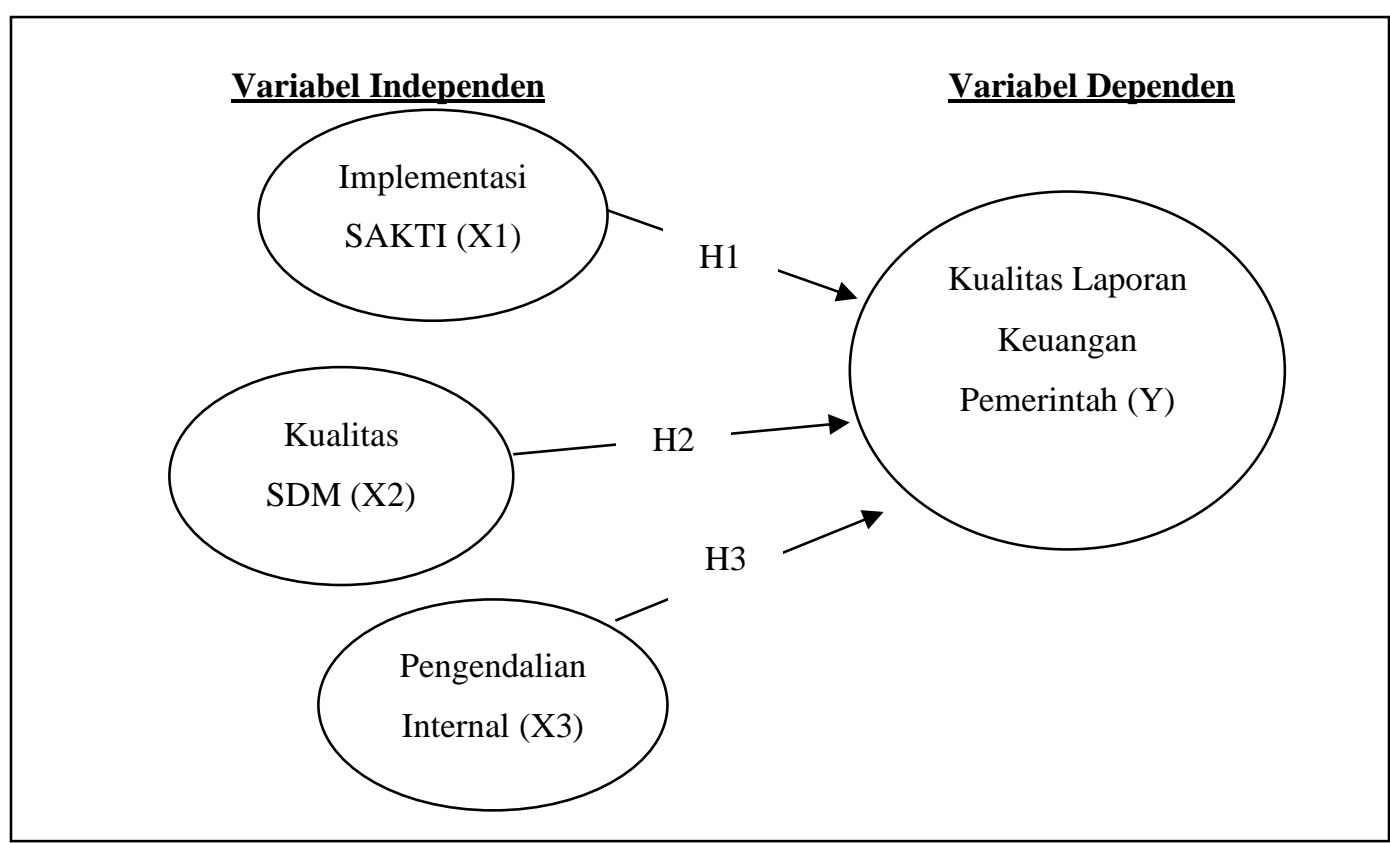

Gambar 1. Kerangka Pemikiran 


\section{Pengembangan Hipotesis}

\section{- Pengaruh Implementasi SAKTI Terhadap Kualitas Laporan Keuangan Pemerintah}

Sistem informasi akuntansi dapat didefinisikan sebagai integrasi dari komponen yang saling berhubungan dan bekerja sama satu sama lain secara harmonis untuk mengolah data transaksi yang berkaitan dengan masalah keuangan menjadi informasi keuangan (Susanto, 2017. Penggunaan sistem informasi teknologi berpengaruh positif terhadap kualitas laporan keuangan (Salehi dan Torabi, 2012; Nurillah, 2014; Ramadan, 2015; Sagara, 2015; Anwar dan Mukadarul, 2016; Rahman dan Fachri, 2016; Synthia, 2016; Lubis, 2017; Anggadini, 2018; Mardinan et.al.,2018; Muda et.al., 2018; Romanti, 2018; Dewi dan Yadnyana, 2019; Hapsari et.al., 2019; Ratmono, 2019; Samosir dan Setiyawati, 2019; Wibowo dan Darmanto, 2019). Berdasarkan uraian di atas dapat dirangkum hipotesis penelitian adalah sebagai berikut :

H1 : Terdapat pengaruh positif implementasi SAKTI terhadap kualitas laporan keuangan pemerintah

\section{- Pengaruh Kompetensi Sumber Daya Manusia Terhadap Kualitas Laporan Keuangan Pemerintah}

Pengembangan kompetensi sumber daya manusia dapat meningkatkan kualitas kinerjanya melalui laporan keuangan (Saleh, 2013). Kompetensi sumber daya manusia memberikan kontribusi terwujudnya laporan keuangan yang berkualitas. Hasil penelitian menyatakan bahwa kompetensi sumber daya manusia berpengaruh positif terhadap laporan keuangan. (Nurillah, 2014; Ramadan, 2015; Sagara, 2015; Anwar dan Mukadarul, 2016; Simon et.al., 2016; Synthia, 2016; Heksarini dan Nadir, 2017; Lubis, 2017; Nurlis dan Yadiati, 2017; Mardinan et.al., 2018; Muthaher, 2018; Novyarni dan Aprileny, 2018; Romanti, 2018; Dewi dan Yadnyana, 2019; Hapsari et.al., 2019; Ratmono, 2019; Samosir dan Setiyawati, 2019). Berdasarkan uraian di atas dapat dirangkum hipotesis penelitian adalah sebagai berikut :

$\mathrm{H} 2$ : Terdapat pengaruh positif kompetensi sumber daya manusia terhadap kualitas laporan keuangan pemerintah

\section{- Pengaruh Pengendalian Internal Terhadap Kualitas Laporan Keuangan Pemerintah}

Pengendalian internal dirancang untuk memberikan keyakinan memadai tentang pencapaian tujuan yang berkaitan dengan operasi, pelaporan, dan kepatuhan (COSO, 2013). Salah satu tujuan dilaksanakannya pengendalian internal adalah meningkatkan keandalan pelaporan keuangan. Semakin efektifnya pengendalian internal maka semakin andal kualitas laporan keuangan.

Hasil penelitian menyatakan bahwa pengendalian internal memiliki pengaruh positif terhadap laporan keuangan (Nurillah, 2014; Ramadan, 2015; Anwar dan Mukadarul, 2016; Samriraay, 2016; Heksarini dan Nadir, 2017; Kewo dan Afiah, 2017; Lubis, 2017; Mardinan et.al., 2018; Muda et.al., 2018; Muthaher, 2018; Romanti, 2018; Dewi dan Yadnyana, 2019; Mulyadi dan Haryoso, 2019; Ratmono, 2019; Samosir dan Setiyawati, 2019; Utaminingtyas, 2019; Wibowo dan Darmanto, 2019). Berdasarkan uraian di atas dapat dirangkum hipotesis penelitian adalah sebagai berikut :

H3 : Terdapat pengaruh positif pengendalian internal terhadap kualitas laporan keuangan pemerintah

\section{METODELOGI PENELITIAN \\ Desain Penelitian}

Penelitian ini merupakan penelitian kausal dengan menguji hipotesis pengaruh variabel independen terhadap variabel dependen. Penelitian ini menggunakan pendekatan kuantitatif.. Variabel bebas (independent variable) yang disimbolkan dengan (X) merupakan variabel yang mempengaruhi variabel terikat yaitu Implementasi SAKTI, Kompetensi Sumber Daya Manusia, dan Pengendalian Internal. Sedangkan variabel terikat (dependent variable) adalah Kualitas Laporan Keuangan Pemerintah. 
JURNAL AKUNTANSI, Vol. 10, No. 1, April (2021)

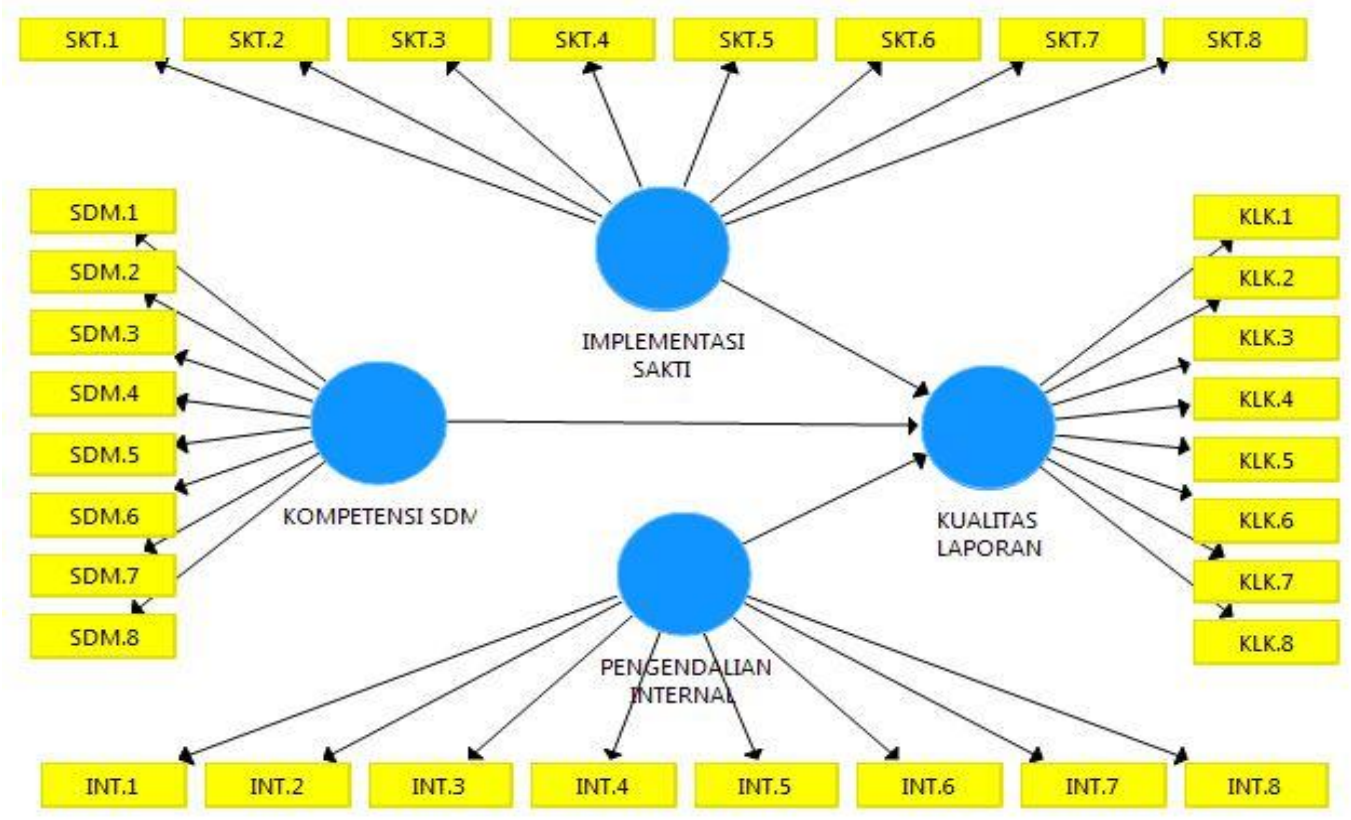

Gambar 2. Model Design Penelitian

\section{Operasionalisasi Variabel Penelitian}

Operasionalisasi variabel diperlukan untuk menentukan jenis, indikator, serta skala dari variabel penelitian. Berikut adalah operasionalisasi variabel penelitian.

Tabel 4. Operasionalisasi Variabel

\begin{tabular}{|c|c|c|c|}
\hline Variabel & Konsep Variabel & Indikator Pertanyaan & Sumber Referensi \\
\hline $\begin{array}{l}\text { Implementasi } \\
\text { SAKTI (X1) } \\
\text { Independent } \\
\text { Variable }\end{array}$ & $\begin{array}{c}\text { Implementasi } \\
\text { SAKTI } \\
\text { merupakan } \\
\text { penggunaan } \\
\text { aplikasi } \\
\text { terintegrasi dalam } \\
\text { proses } \\
\text { pengelolaan } \\
\text { keuangan negara, } \\
\text { mulai dari } \\
\text { penganggaran, } \\
\text { pelaksanaan } \\
\text { anggaran, sampai } \\
\text { menjadi laporan } \\
\text { keuangan }\end{array}$ & $\begin{array}{l}\text { 1) Kestabilan aplikasi } \\
\text { 2) Validasi transaksi } \\
\text { 3) Periode unaudited dan } \\
\text { audited } \\
\text { 4) Pembentukan jurnal } \\
\text { 5) Tutup buku } \\
\text { 6) Pencetakan laporan } \\
\text { 7) Laporan periodik } \\
\text { 8) Rekonsiliasi dan } \\
\text { konsolidasi }\end{array}$ & $\begin{array}{c}\text { Peraturan Menteri } \\
\text { Keuangan Nomor } \\
223 \text { Tahun } 2015\end{array}$ \\
\hline $\begin{array}{l}\text { Kompetensi } \\
\text { Sumber Daya } \\
\text { Manusia (X2) } \\
\text { Independent } \\
\text { Variable }\end{array}$ & $\begin{array}{c}\text { Kompetensi SDM } \\
\text { adalah } \\
\text { pengetahuan, } \\
\text { keterampilan, dan } \\
\text { sikap perilaku } \\
\text { yang diperlukan } \\
\text { dalam } \\
\text { pelaksanaan tugas } \\
\text { jabatannya, } \\
\text { termasuk dalam } \\
\text { penyusunan } \\
\text { laporan keuangan }\end{array}$ & $\begin{array}{ll}\text { 1) } & \text { Memahami peraturan } \\
\text { 2) } & \text { Membaca literatur } \\
& \text { akuntansi } \\
\text { 3) } & \text { Membaca juknis } \\
\text { pelaporan } \\
\text { 4) Kemampuan } \\
\text { mengoperasikan } \\
\text { aplikasi keuangan } \\
\text { 5) Kemampuan analisis } \\
\text { laporan } \\
\text { 6) Mengikuti pelatihan } \\
\text { 7) } \text { Bekerja sesuai prosedur }\end{array}$ & $\begin{array}{c}\text { Keputusan Kepala } \\
\text { BKN Nomor 46A } \\
\text { Tahun } 2003\end{array}$ \\
\hline
\end{tabular}


JURNAL AKUNTANSI, Vol. 10, No. 1, April (2021)

\begin{tabular}{|c|c|c|c|c|}
\hline Variabel & Konsep Variabel & & Indikator Pertanyaan & Sumber Referensi \\
\hline & & 8) & Menolak intervensi & \\
\hline $\begin{array}{c}\text { Pengendalian } \\
\text { Internal (X3) } \\
\text { Independent } \\
\text { Variable }\end{array}$ & $\begin{array}{c}\text { Pengendalian } \\
\text { internal adalah } \\
\text { proses, } \\
\text { dipengaruhi oleh } \\
\text { entitas direksi, } \\
\text { manajemen, dan } \\
\text { personel lain, } \\
\text { yang dirancang } \\
\text { untuk } \\
\text { memberikan } \\
\text { keyakinan } \\
\text { memadai tentang } \\
\text { pencapaian tujuan } \\
\text { yang berkaitan } \\
\text { dengan operasi, } \\
\text { pelaporan, dan } \\
\text { kepatuhan }\end{array}$ & $\begin{array}{l}\text { 1) } \\
\text { 2) } \\
\text { 3) } \\
\text { 4) } \\
\text { 5) } \\
\text { 6) } \\
\text { 7) } \\
\text { 8) }\end{array}$ & $\begin{array}{l}\text { Pendefinisian } \\
\text { wewenang } \\
\text { Otorisasi transaksi } \\
\text { Prosedur pengeluaran } \\
\text { aktiva } \\
\text { Pola mutasi pegawai } \\
\text { Pembinaan dari Kantor } \\
\text { Wilayah } \\
\text { Kelengkapan informasi } \\
\text { transaksi } \\
\text { Rapat secara berkala } \\
\text { Evaluasi pimpinan } \\
\text { terhadap temuan }\end{array}$ & COSO, 2013 \\
\hline Kualitas & Kualitas Laporan & 1) & Tepat waktu & Peraturan \\
\hline Laporan & Keuangan & 2) & Lengkap & Pemerintah Nomor \\
\hline Keuangan & Pemerintah & 3) & Jujur & 71 Tahun 2010 \\
\hline Pemerintah $(\mathrm{Y})$ & merupakan syarat & 4) & Kesalahan tidak & \\
\hline Dependent & agar laporan bisa & & material & \\
\hline Variable & menyajikan & 5) & Dapat diuji & \\
\hline & informasi yang & 6) & Netral & \\
\hline & $\begin{array}{l}\text { bermanfaat bagi } \\
\text { para pengguna } \\
\text { dalam menilai }\end{array}$ & 7) & $\begin{array}{l}\text { Dapat dibandingkan } \\
\text { dengan periode } \\
\text { sebelumnya }\end{array}$ & \\
\hline & $\begin{array}{c}\text { akuntabilitas dan } \\
\text { membuat } \\
\text { keputusan }\end{array}$ & 8) & $\begin{array}{l}\text { Informasi dapat } \\
\text { dipahami }\end{array}$ & \\
\hline
\end{tabular}

Sumber : Diolah

\section{HASIL DAN PEMBAHASAN}

\section{Hasil}

Uji Validitas Instrumen PenelitiaN

Pengujian validitas menggunakan 32 (tiga puluh dua) butir pertanyaan. Hasil pengujian validitas instrumen penelitian disajikan pada tabel dibawah ini.

Tabel 7. Hasil Uji Validitas Instrumen Penelitian

\begin{tabular}{cccc}
\hline Variabel & Pertanyaan & Loading Factor & Keterangan \\
\hline Implementasi SAKTI & 1 & 0.643 & Valid \\
Implementasi SAKTI & 2 & 0.610 & Valid \\
Implementasi SAKTI & 3 & 0.171 & Tidak Valid \\
Implementasi SAKTI & 4 & 0.610 & Valid \\
Implementasi SAKTI & 5 & 0.540 & Valid \\
Implementasi SAKTI & 6 & 0.534 & Valid \\
Implementasi SAKTI & 7 & 0.753 & Valid \\
Implementasi SAKTI & 8 & 0.804 & Valid \\
Kompetensi SDM & 1 & 0.712 & Valid \\
Kompetensi SDM & 2 & 0.867 & Valid
\end{tabular}


JURNAL AKUNTANSI, Vol. 10, No. 1, April (2021)

\begin{tabular}{cccc}
\hline Variabel & Pertanyaan & Loading Factor & Keterangan \\
\hline Kompetensi SDM & 3 & 0.881 & Valid \\
Kompetensi SDM & 4 & 0.841 & Valid \\
Kompetensi SDM & 5 & 0.882 & Valid \\
Kompetensi SDM & 6 & 0.512 & Valid \\
Kompetensi SDM & 7 & 0.636 & Valid \\
Kompetensi SDM & 8 & 0.833 & Valid \\
Pengendalian Internal & 1 & 0.803 & Valid \\
Pengendalian Internal & 2 & 0.716 & Valid \\
Pengendalian Internal & 3 & 0.864 & Valid \\
Pengendalian Internal & 4 & 0.105 & Tidak Valid \\
Pengendalian Internal & 5 & 0.296 & Tidak Valid \\
Pengendalian Internal & 6 & 0.594 & Valid \\
Pengendalian Internal & 7 & 0.174 & Tidak Valid \\
Pengendalian Internal & 8 & 0.758 & Valid \\
Kualitas Laporan Keuangan & 1 & 0.733 & Valid \\
Kualitas Laporan Keuangan & 2 & 0.685 & Valid \\
Kualitas Laporan Keuangan & 3 & 0.797 & Valid \\
Kualitas Laporan Keuangan & 4 & 0.827 & Valid \\
Kualitas Laporan Keuangan & 5 & 0.778 & Valid \\
Kualitas Laporan Keuangan & 6 & 0.431 & Tidak Valid \\
Kualitas Laporan Keuangan & 7 & 0.785 & Valid \\
Kualitas Laporan Keuangan & 8 & 0.860 & Valid \\
\hline
\end{tabular}

Sumber : Diolah (2020)

Berdasarkan tabel 7 diatas pertanyaan yang tidak memenuhi syarat validitas akan dihilangkan.

\section{Uji Reliabilitas Instrumen Penelitian}

Uji reliabilitas adalah untuk menguji kualitas instrumen penelitian dengan mengukur konsistensi seluruh pertanyaan dalam penelitian. Suatu konstruk atau variabel dikatakan reliabel jika memberikan nilai cronbach's alpha dan composite reliability lebih besar dari 0,7. Hasil pengujian reliabilitas instrumen penelitian disajikan pada tabel dibawah ini.

Tabel 8. Hasil Uji Reliabilitas

\begin{tabular}{lccc}
\hline \multicolumn{1}{c}{ Variabel } & $\begin{array}{c}\text { Cronbach's } \\
\text { Alpha }\end{array}$ & $\begin{array}{c}\text { Composite } \\
\text { Reliability }\end{array}$ & Keterangan \\
\hline Implementasi SAKTI & 0.751 & 0.813 & Reliabel \\
Kompetensi Sumber Daya Manusia & 0.903 & 0.924 & Reliabel \\
Pengendalian Internal & 0.706 & 0.787 & Reliabel \\
Kualitas Laporan Keuangan & 0.880 & 0.908 & Reliabel \\
\hline
\end{tabular}

Sumber : Data diolah (2020)

Berdasarkan tabel 8, hasil uji reliabilitas pada tabel di atas, nilai cronbach's alpha dan composite reliability pada masing-masing variabel lebih besar dari 0,7 dan dinyatakan reliabel.

\section{Uji Ketepatan Model Pengukuran (Outer Model)}

Validitas hubungan antara indikator dengan variabel laten dilakukan dengan validitas konvergen. Validitas konvergen terjadi jika skor yang diperoleh dari dua instrumen yang berbeda yang. Uji validitas konvergen dengan program SmartPLS dapat dilihat dari nilai loading factor untuk tiap indikator konstruk. Nilai muatan (loading) memiliki tingkat validitas yang tinggi apabila memiliki loading factor lebih besar dari 0,70. Nilai loading di atas 0,5 masih dianggap valid. Hasil pengujian nilai loading factor penelitian disajikan pada tabel didawah ini. 
JURNAL AKUNTANSI, Vol. 10, No. 1, April (2021)

Tabel 9. Nilai Loading Factor Indikator

\begin{tabular}{ccc}
\hline Variabel & Indikator & Loading Factor \\
\hline Implementasi SAKTI & SKT1 & 0,699 \\
Implementasi SAKTI & SKT2 & 0,703 \\
Implementasi SAKTI & SKT4 & 0,760 \\
Implementasi SAKTI & SKT5 & 0,682 \\
Implementasi SAKTI & SKT6 & 0,785 \\
Implementasi SAKTI & SKT7 & 0,800 \\
Implementasi SAKTI & SKT8 & 0,831 \\
Kompetensi SDM & SDM1 & 0,666 \\
Kompetensi SDM & SDM2 & 0,663 \\
Kompetensi SDM & SDM3 & 0,807 \\
Kompetensi SDM & SDM4 & 0,821 \\
Kompetensi SDM & SDM5 & 0,775 \\
Kompetensi SDM & SDM6 & 0,694 \\
Kompetensi SDM & SDM7 & 0,593 \\
Kompetensi SDM & SDM8 & 0,691 \\
Pengendalian Internal & INT1 & 0,799 \\
Pengendalian Internal & INT2 & 0,785 \\
Pengendalian Internal & INT3 & 0,715 \\
Pengendalian Internal & INT6 & 0,753 \\
Pengendalian Internal & INT8 & 0,726 \\
Kualitas Laporan Keuangan & KLK1 & 0,576 \\
Kualitas Laporan Keuangan & KLK2 & 0,774 \\
Kualitas Laporan Keuangan & KLK3 & 0,896 \\
Kualitas Laporan Keuangan & KLK4 & 0,818 \\
Kualitas Laporan Keuangan & KLK5 & 0,854 \\
Kualitas Laporan Keuangan & KLK7 & 0,755 \\
Kualitas Laporan Keuangan & KLK8 & 0,746 \\
\hline
\end{tabular}

Sumber : Data diolah (2020)

Validitas konvergen dengan melihat nilai Average Variance Extracted (AVE). Konstruk memiliki tingkat validitas yang tinggi apabila nilai AVE lebih besar dari 0,70. Hasil pengujian nilai AVE penelitian disajikan pada tabel 10.

Tabel 10. Nilai AVE Indikator

\begin{tabular}{cc}
\hline Variabel & Nilai AVE \\
\hline Implementasi SAKTI & 0,567 \\
Kompetensi SDM & 0,515 \\
Pengendalian Internal & 0,572 \\
Kualitas Laporan Keuangan Pemerintah & 0,609 \\
\hline
\end{tabular}

Sumber : data primer diolah (2020)

Berdasarkan hasil pengolahan yang ditunjukkan pada tabel 10, indikator variabel memiliki nilai loading factor lebih besar dari 0,50 dan lebih kecil dari 0,70 sehingga seluruh indikator telah memenuhi syarat validitas konvergen. 


\section{Validitas Diskriminan}

Validitas diskriminan mengukur dua konstruk yang diprediksikan tidak berkorelasi. Hasil pengujian validitas diskriminan penelitian disajikan pada Tabel 11.

Tabel 11. Nilai Cross Loading

\begin{tabular}{ccccc}
\hline Indikator & SKT & SDM & INT & KLK \\
\hline SKT1 & $\mathbf{0 , 6 9 9}$ & 0,467 & 0,406 & 0,448 \\
SKT2 & $\mathbf{0 , 7 0 3}$ & 0,288 & 0,169 & 0,458 \\
SKT4 & $\mathbf{0 , 7 6 0}$ & 0,467 & 0,469 & 0,507 \\
SKT5 & $\mathbf{0 , 6 8 2}$ & 0,397 & 0,440 & 0,506 \\
SKT6 & $\mathbf{0 , 7 8 5}$ & 0,431 & 0,579 & 0,682 \\
SKT7 & $\mathbf{0 , 8 0 0}$ & 0,374 & 0,485 & 0,668 \\
SKT8 & $\mathbf{0 , 8 3 1}$ & 0,392 & 0,473 & 0,617 \\
SDM1 & 0,351 & $\mathbf{0 , 6 6 6}$ & 0,377 & 0,303 \\
SDM2 & 0,376 & $\mathbf{0 , 6 6 3}$ & 0,381 & 0,294 \\
SDM3 & 0,400 & $\mathbf{0 , 8 0 7}$ & 0,457 & 0,403 \\
SDM4 & 0,370 & $\mathbf{0 , 8 2 1}$ & 0,481 & 0,403 \\
SDM5 & 0,396 & $\mathbf{0 , 7 7 5}$ & 0,544 & 0,431 \\
SDM6 & 0,373 & $\mathbf{0 , 6 9 4}$ & 0,533 & 0,437 \\
SDM7 & 0,338 & $\mathbf{0 , 5 9 3}$ & 0,315 & 0,314 \\
SDM8 & 0,435 & $\mathbf{0 , 6 9 1}$ & 0,443 & 0,409 \\
INT1 & 0,532 & 0,432 & $\mathbf{0 , 7 9 9}$ & 0,564 \\
INT2 & 0,422 & 0,417 & $\mathbf{0 , 7 8 5}$ & 0,417 \\
INT3 & 0,361 & 0,374 & $\mathbf{0 , 7 1 5}$ & 0,379 \\
INT6 & 0,379 & 0,572 & $\mathbf{0 , 7 5 3}$ & 0,520 \\
INT8 & 0,498 & 0,546 & $\mathbf{0 , 7 2 6}$ & 0,501 \\
KLK1 & 0,568 & 0,272 & 0,474 & $\mathbf{0 , 5 7 6}$ \\
KLK2 & 0,671 & 0,487 & 0,638 & $\mathbf{0 , 7 7 4}$ \\
KLK3 & 0,591 & 0,489 & 0,519 & $\mathbf{0 , 8 9 6}$ \\
KLK4 & 0,626 & 0,463 & 0,490 & $\mathbf{0 , 8 1 8}$ \\
KLK5 & 0,578 & 0,498 & 0,526 & $\mathbf{0 , 8 5 4}$ \\
KLK7 & 0,472 & 0,188 & 0,392 & $\mathbf{0 , 7 5 5}$ \\
KLK8 & 0,536 & 0,417 & 0,388 & $\mathbf{0 , 7 4 6}$ \\
\hline
\end{tabular}

Sumber : Data Diolah (2020)

Berdasarkan hasil cross loading di atas menunjukkan bahwa nilai korelasi konstruk dengan indikatornya lebih besar daripada nilai korelasi dengan konstruk lainnya sehingga semua konstruk atau variabel sudah memiliki discriminant validity.

\section{Reliabilitas}

Suatu konstruk atau variabel dikatakan reliabel jika memberikan nilai cronbach's alpha dan composite reliability lebih besar dari 0,7 . Hasil pengujian reliabilitas penelitian disajikan pada Tabel 12.

Tabel 12. Nilai Cronbach's Alpha dan Composite Reliability

\begin{tabular}{lcc}
\hline \multicolumn{1}{c}{ Variabel } & $\begin{array}{c}\text { Cronbach's } \\
\text { Alpha }\end{array}$ & $\begin{array}{c}\text { Composite } \\
\text { Reliability }\end{array}$ \\
\hline Implementasi SAKTI & 0.873 & 0.901 \\
Kompetensi Sumber Daya Manusia & 0.864 & 0.894 \\
Pengendalian Internal & 0.814 & 0.870 \\
Kualitas Laporan Keuangan Pemerintah & 0.889 & 0.915 \\
\hline
\end{tabular}

Sumber : Data Diolah (2020) 


\section{JURNAL AKUNTANSI, Vol. 10, No. 1, April (2021)}

Berdasarkan hasil uji reliabilitas pada tabel di atas, nilai cronbach's alpha dan composite reliability pada masing-masing variabel lebih besar dari 0,7, sehingga disimpulkan bahwa semua konstruk memiliki reliabilitas optimal atau mampu untuk mengukur konstruknya.

\section{Uji Kecocokan Model Struktural (Inner Model)}

Inner model menggambarkan hubungan antar variabel berdasarkan pada substantive theory. Model struktural untuk konstruk dependen dievaluasi dengan menggunakan $R$-Square atau uji determinasi. Nilai $R$-Square disajikan pada Tabel 13.

Tabel 13. Nilai $R$-Square

\begin{tabular}{ccc}
\hline Variabel & $R$-Square & $R$-Square Adjusted \\
\hline Kualitas Laporan Keuangan Pemerintah & 0,628 & 0,615 \\
\hline
\end{tabular}

Sumber : Data Diolah (2020)

Nilai $R$-Square adalah 0,628 dan nilai $R$-Square Adjusted sebesar 0,615, sehingga dapat diartikan bahwa Kualitas Laporan Keuangan Pemerintah dapat dijelaskan oleh implementasi SAKTI, Kompetensi SDM, dan Pengendalian Internal sebesar 62,8\%. Sisanya dijelaskan oleh variabel lainnya di luar model penelitian.

\section{Uji Hipotesis}

Guna mengetahui suatu hipotesis itu dapat diterima atau ditolak diantaranya dengan memperhatikan nilai signifikansi antar konstruk, $t$-statistik, dan $p$-values. Kriteria (rule of the thumb) yang digunakan pada penelitian ini adalah $t$-statistik $>t$-table. Nilai $t$-table dengan degree of freedom 87 dan tingkat signifikansi $p$-value $0,05(5 \%)$ adalah 1,66256. Nilai pengujian hipotesis penelitian disajikan pada Tabel 14 dan untuk hasil model penelitian ini digambarkan pada tabel 14 .

Tabel 14. Hasil Path Coefficients

\begin{tabular}{cccccc}
\hline Hipotesis & $\begin{array}{c}\text { Original } \\
\text { Sample (O) }\end{array}$ & $\begin{array}{c}\text { Sample } \\
\text { Mean (M) }\end{array}$ & $\begin{array}{c}\text { Standard } \\
\text { Deviation } \\
\text { (STDEV) }\end{array}$ & $\begin{array}{c}\text { T Statistics } \\
(|\mathrm{O} / \mathrm{STDEV}|)\end{array}$ & P Values \\
\hline SKT -> KLK & 0,556 & 0,553 & 0,081 & 6,907 & 0,000 \\
SDM -> KLK & 0,063 & 0,081 & 0,103 & 0,614 & 0,270 \\
INT -> KLK & 0,275 & 0,270 & 0,095 & 2,885 & 0,002 \\
\hline
\end{tabular}

Sumber : Data Diolah (2020) 


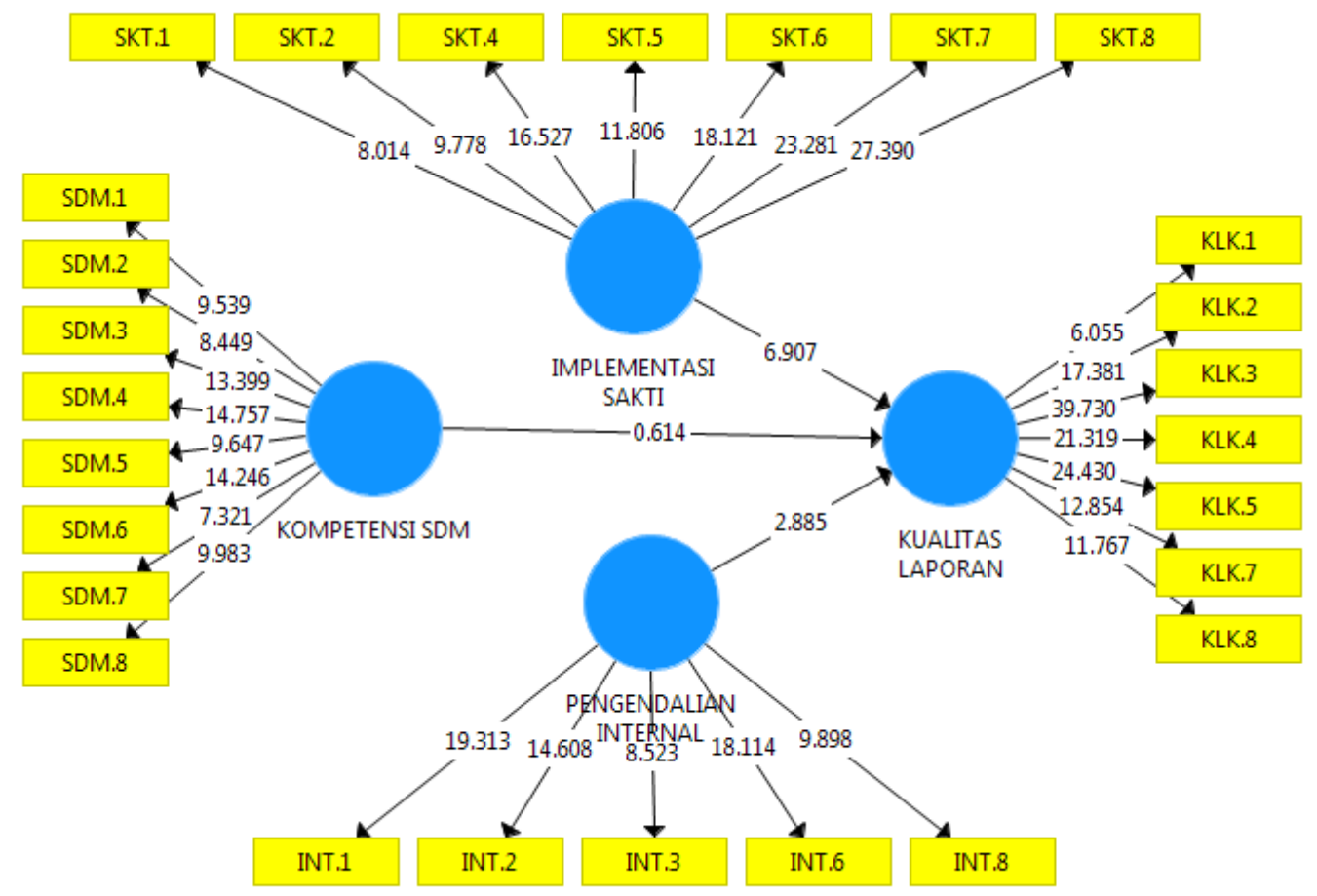

Gambar 3. Hasil Model Penelitian

Berdasarkan hasil olah data diatas dapat dibuatkan persamaan linear regresi sebagai berikut :

Dimana :

$$
\mathbf{Y}=\beta_{1} \mathbf{6 , 9 0 7} X_{1}+\beta_{2} \mathbf{0 , 6 1 4} X_{2}+\beta_{3} 2,855 X_{3}+\varepsilon
$$

Y : Kualitas Laporan Keuangan

$X_{1}:$ Implementasi SAKTI

$X_{2} \quad$ : Kompetensi SDM

$X_{3} \quad$ Pengendalian Internal

$\beta \quad:$ Koefisien regresi

$\varepsilon \quad:$ Error

Dapat disimpulkan bahwa bila implementasi SAKTI naik 1 satuan maka kualitas laporan keuangan akan meningkat sebesar 6,907 satuan. Kemudian bila kompetensi SDM naik 1 satuan maka kualitas laporan keuangan akan meningkat sebesar 0,614 satuan. Kemudian bila pengendalian internal naik 1 satuan maka kualitas laporan keuangan naik sebesar 2,855 satuan.

Hipotesis pertama menyatakan terdapat pengaruh positif implementasi SAKTI terhadap kualitas laporan keuangan pemerintah. Hasil pengujian menunjukkan nilai $t$-statistik sebesar 6,907 yang lebih besar dibandingkan nilai t-tabel $(1,66256)$ dan tingkat signifikansi $(P$ Values $) 0,000$ di bawah 0,05 , sehingga hipotesis pertama diterima. Hal tersebut membuktikan bahwa implementasi SAKTI memiliki pengaruh positif dan signifikan terhadap kualitas laporan keuangan pemerintah.

Hipotesis kedua menyatakan terdapat pengaruh positif kompetensi sumber daya manusia terhadap kualitas laporan keuangan pemerintah. Hasil pengujian menunjukkan nilai $t$-statistik sebesar 0,614 yang lebih kecil dibandingkan nilai $t$-tabel $(1,66256)$ dan tingkat signifikansi $(P$ Values $) 0,270$ di atas 0,05 , sehingga hipotesis kedua ditolak. Hal tersebut membuktikan bahwa kompetensi sumber daya manusia tidak memiliki pengaruh signifikan terhadap kualitas laporan keuangan pemerintah. 


\section{JURNAL AKUNTANSI, Vol. 10, No. 1, April (2021)}

Hipotesis ketiga menyatakan terdapat pengaruh positif pengendalian internal terhadap kualitas laporan keuangan pemerintah. Hasil pengujian menunjukkan nilai $t$-statistik sebesar 2,885 yang lebih besar dibandingkan nilai t-tabel $(1,66256)$ dan tingkat signifikansi ( $P$ Values) 0,002 di bawah 0,05 , sehingga hipotesis ketiga diterima. Hal tersebut membuktikan bahwa pengendalian internal memiliki pengaruh positif dan signifikan terhadap kualitas laporan keuangan pemerintah.

\section{PEMBAHASAN}

Penelitian ini membuktikan bahwa terdapat pengaruh positif dan signifikan antara implementasi SAKTI terhadap kualitas laporan keuangan pemerintah. Implementasi SAKTI merupakan salah satu faktor yang dapat menghasilkan laporan keuangan pemerintah yang berkualitas. Semakin baik sistem informasi keuangan, maka akan semakin tinggi kualitas laporan keuangan yang dihasilkan. Hasil penelitian ini sejalan penelitian Mardinand et.al (2018) yang juga meneliti tentang pengaruh penggunaan sistem informasi terhadap kualitas laporan keuangan.

Penelitian ini membuktikan pengaruh kompetensi sumber daya manusia terhadap kualitas laporan keuangan pemerintah tidak signifikan. Hal ini menyimpulkan aplikasi SAKTI tidak membutuhkan tingkat keahlian SDM yang tinggi khususnya dalam mengoperasikan sistem aplikasi. Kemampuan SDM yang dibutuhkan cukup dengan tingkat rata-rata. dan memahami proses mengoperasikan aplikasi SAKTI. Hasil penelitian ini sejalan dengan kesimpulan Desipradani dan Nuraini (2018), Setyawan (2018), dan Utaminingtyas (2019) bahwa kompetensi sumber daya manusia tidak berpengaruh signifikan terhadap kualitas laporan keuangan Pemerintah.

Selanjutnya penelitian ini membuktikan terdapat pengaruh positif signifikan antara pengendalian internal terhadap kualitas laporan keuangan pemerintah. Pengendalian internal merupakan salah satu faktor yang dapat menghasilkan laporan keuangan pemerintah berkualitas. Semakin baik pengendalian internal maka akan semakin tinggi kualitas laporan keuangan yang dihasilkan. Hasil penelitian ini sejalan dengan kesimpulan penelitian Desipradani dan Nuraini (2018).

\section{PENUTUP \\ Simpulan}

Berdasarkan hasil pengolahan data penelitian dan pengujian yang telah dilakukan dapat simpulkan bahwa implementasi SAKTI pengaruh positif signifikan terhadap kualitas laporan keuangan Pemerintah. Semakin optimal implementasi SAKTI maka semakin tinggi kualitas laporan keuangan. Selanjutnya kompetensi SDM tidak berpengaruh signifikan terhadap kualitas laporan keuangan pemerintah. Hal ini dapat diartikan bahwa kompetensi SDM yang dibutuhkan dalam mengoperasikan aplikasi SAKTI tidak harus tinggi cukup dengan kemampuan rata-rata sudah dapat mengoperasikan dan memahami aplikasi. Berikutnya adalah pengaruh pengendalian internal terhadap kualitas laporan keuangan Pemerintah berpengaruh positif signifikan. Semakin optimal pengendalian internal semakin tinggi tingkat kualitas laporan keuangan Pemerintah.

\section{Saran}

Penelitian ini terbatas dilakukan instansi Pemerintah dan dapat dilakukan dengan objek berbeda misalnya di perusahaan atau lembaga swasta lainnya. Penelitian selanjutnya dapat memperluas model penelitian dengan menambah variabel relevan lainnya yang dapat mempengaruhi kualitas laporan keuangan pemerintah. Populasi dan sampel penelitian dapat diperluas dengan melibatkan lintas instansi Pemerintah. Keberhasilan implementasi SAKTI dalam meningkatkan kualitas laporan keuangan dapat dipertahankan dan ditingkatkan. Kompetensi SDM perlu dijaga kestabilannya sehingga dapat mengoperasikan aplikasi SAKTI secara optimal. Penerapan pengendalian internal sudah cukup memadai dan perlu ditingkatkan. Pengawas internal secara periodik melakukan aktivitas audit, reviu, evaluasi, dan kegiatan pengawasan lainnya terhadap operasional instansi khususnya dibidang keuangan agar laporan keuangan yang dihasilkan berkualitas tinggi. 


\section{REFRENSI}

Abnur, A. 2018. Jurus Menteri Asman untuk Sembuhkan Penyakit Birokrasi. https://www.menpan.go.id/site/berita-terkini/jurus-menteri-asman-untuk-sembuhkan-penyakitbirokrasi, diakses 10 Juni 2020.

Anggadini, S. D. (2018). Quality Of Financial Information Management System On Quality Of Financial Statements Of Local Government. Jurnal Ilmiah Akuntansi, 9, 113-117.

Anwar, C. \& Mukadarul, D. M. (2016). The Influence Of Human Resources, Commitment Leader, The Use Of Information Technology, And System Internal Control On The Quality Of Local Government Financial Report Pringsewu. Makalah disampaikan dalam The Third International Conference on Law, Business and Government: Bandar Lampung, 21 Mei 2016.

Badan Pemeriksa Keuangan RI. (2014). Laporan Hasil Pemeriksaan atas Laporan Keuangan Pemerintah Pusat Tahun 2014. Jakarta: BPK RI.

Badan Pemeriksa Keuangan RI. (2015). Laporan Hasil Pemeriksaan atas Laporan Keuangan Pemerintah Pusat Tahun 2015. Jakarta: BPK RI.

Badan Pemeriksa Keuangan RI. (2016). Laporan Hasil Pemeriksaan atas Laporan Keuangan Pemerintah Pusat Tahun 2016. Jakarta: BPK RI.

Badan Pemeriksa Keuangan RI. (2017). Laporan Hasil Pemeriksaan atas Laporan Keuangan Pemerintah Pusat Tahun 2017. Jakarta: BPK RI.

Badan Pemeriksa Keuangan RI. (2018). Laporan Hasil Pemeriksaan atas Laporan Keuangan Pemerintah Pusat Tahun 2018. Jakarta: BPK RI.

Badan Pengawas Keuangan dan Pembangunan. 2015. Kompetensi. http://www.bpkp.go.id/sesma/konten/244/mac-kompetensi, diakses 2 Maret 2020.

Committee of Sponsoring Organization (COSO) of The Treadway Commission. (2013). Internal Control - Integrated Framework: Executive Summary. COSO.

Desipradani, G., Nuraini, F., Surabaya, U. M., \& Surabaya, P. K. (2018). Variabel Berpengaruh Terhadap Kualitas Laporan Keuangan Pemerintah Kota Surabaya. Majalah Ekonomi, 23.

Direktorat Sistem Informasi dan Teknologi Perbendaharaan. (2015). Nilai Kelas Pelaporan End User Training SAKTI. SITP: Jakarta. (Tidak dipublikasikan).

Direktorat Sistem Informasi dan Teknologi Perbendaharaan. 2020. Nexus Repository Manager OSS SAKTI. http://10.242.99.41:8081/nexus/\#view-repositories, diakses 1 Maret 2020.

Febriyanto, I. I. 2012. Studi Komparasi Teori New Public Management dengan Good Governance dalam Perspektif Kebijakan Publik. http://lintassosialpolitik.blogspot.com/2012/10/teori-newpublic-management.html, diakses 14 Maret 2020.

Ghozali, I., \& Latan, H. (2014). Structural Equation Modeling, Metode Alternatif dengan Partial Least Square (PLS). Badan Penerbit Universitas Diponegoro: Semarang.

Hapsari, A., Nurlaela, S., \& Titisari, K. H. (2019). Human Resources Optimization And Utilization Of Accrual Based Accounting Information Technology On Performance Of Surakarta City Government Financial Reporting. International Journal of Economics, Business, And Accounting Research (IJEBAR), 3(1), 1-6.

Hartono, B. (2013). Sistem Informasi Manajemen Berbasis Komputer. Rineka Cipta: Jakarta.

Heksarini, A., \& Nadir, M. (2017). Influencing Factor Analysis To The Information Quality Of Samarinda Government Financial Statement. Journal Research and Analysis : Accounting and Financial, 4, 1-7.

Hood, C. (1991). A Public Management for All Seasons. Public Administration, 69, 3-19.

Kartikahadi, H. (2016). Akuntansi Keuangan Berdasarkan SAK Berbasis IFRS. Salemba Empat: Jakarta.

Kementerian Keuangan RI. 2019. Rekap Status SLA Tiket HAI DJPb. HAI DJPb: Jakarta.

Kementerian Keuangan RI. 2020. Profil Ditjen Perbendaharaan. https://djpb.kemenkeu.go.id/portal/id/, diakses 14 April 2020.

Kewo, C. L., \& Afiah, N. N. (2017). Does Quality of Financial Statement Affected by Internal Control System and Internal Audit? International Journal of Economics and Financial Issues, 7(2), 568573.

Kieso, Donald, E., Weygant, J. J., \& Warfield, T. D. (2012). Akuntansi Intermediate (Terjemahan Gina 
Grahia dan Ichsan Setiyo Budi (ed.); Edisi Kese). Erlangga: Jakarta.

Likierman, A. (2003). Planning and Controlling UK Public Expenditure on a Resource Basis. Public Money \& Management, 23, 45-50.

Lubis, M., Bakar, E. A., \& Natigor, F. (2017). The Influence Of Human Resource Competence, Utilization Of Information Technology, Implementation Of Accrual-Base Government Accounting Standard, And The Implementation Of Government Internal Control System On The Quality Of Government Financial Statement. Universitas Sumatera Utara: Medan. (Tidak dipublikasikan).

Mahmudi. (2015). Manajemen Kinerja Sektor Publik. UPP STIM YKPN: Yogyakarta.

Mardiasmo. (2009). Akuntansi Sektor Publik. Andi: Yogyakarta.

Mardinan, T., Dahlan, M., \& Fitriyah, F. K. (2018). Effect of Human Resources, Leadership Style, The Use of Information Technology and Internal Control on the Quality of Financial Statements. Journal of Accounting Auditing and Business, 1, 43-57.

Maulina, R. 2019. Strategi Pengembangan Potensi Kinerja SDM Melalui Program Pelatihan Karyawan. https://sleekr.co/blog/strategi-pengembangan-potensi-sdm-melalui-pelatihan/, diakses 24 Maret 2020.

Muda, I. (2018). Factors Of Quality Of Financial Report Of Local Government In Indonesia. Earth and Enviromental Science, 8, 68-74.

Mulyadi. P. Haryoso. (2019). Peranan Sistem Pengendalian Internal Dan Penggunaan Teknologi Informasi Dalam Menentukan Kualitas Laporan Keuangan Skpd Kota Surakarta. Ekonomi Dan Perbankan, 4(1), 78-97.

Mulyadi. (2016). Sistem Akuntansi. Salemba Empat: Jakarta.

Muthaher, O. (2018). Fokus Ekonomi. Jurnal Fokus Ekonomi, 13(2), 280-300.

Novyarni, N., \& Aprileny, I. (2019). Effect of Competence and Independence of Intern Auditor and Competence of Human Resource on the Quality of Financial Reporting at the Provincial Government and Municipal Government in Jakarta. 73, 27-31.

Nurillah, A. S. (2014). Pengaruh Kompetensi Sumber Daya Manusia, Pemanfaatan Teknologi Informasi, dan Sistem Keuangan Pemerintah Daerah (Studi Empiris Pada SKPD Kota Depok). Diponegoro Journal of Accounting, 3, 2337-3806.

Nurlis, \& Yudiati, W. (2017). The Influence of Internal Control Effectiveness, Information Technology Utilization and Human Resources Competence on Local Government Financial Reporting Quality ( Survey on SKPD Banten Provincial Government and Serang City ). Research Journal of Finance and Accounting, 8(12), 111-124.

Octaviani, E. (2016). Faktor-faktor yang Berpengaruh Terhadap Penerimaan dan Penggunaan Sistem Manajemen Pembelajaran Exelsa Universitas Sanata Dharma. Universitas Sanata Dharma: Yogyakarta. (Tidak dipublikasikan).

Prabowo, T. J. W., Leung, P., \& Guthrie, J. (2017). Reforms in Public Sector Accounting and Budgeting in Indonesia (2003-2015): Confusions in Implementation. Journal of Public Budgeting, Accounting \& Financial Management, 29, 104-137.

Putu, N., Lestari, D., \& Yadnyana, I. K. (2019). The Influence of Top Management Support , Quality of Human Resources, Accounting Information Systems, Internal Control Systems on the Quality of Financial Reports. International Journal of Management and Commerce Innovations, 7(1), 402-409.

Rahman, A., \& Fachri, Z. (2016). Region's Financial Accounting Information System and the Quality of Local Government Financial Reports. Information Management and Business Review, 8(4), 64-68.

Ramadan, S. (2015). Pengaruh Kompetensi Sumber Daya Manusia Pengelola Keuangan, Pengendalian Intern, Teknologi Informasi Dan Komitmen Organisasi Terhadap Kualitas Laporan Keuangan Pada Satker Kementerian Pekerjaan Umum Direktorat Jenderal Cipta Karya Provinsi Kepri. Universitas Maritim Raja Ali Haji: Tanjung Pinang. (Tidak Dipublikasikan).

Republik Indonesia. 2003a. Keputusan Kepala Badan Kepegawaian Negara Nomor 46A Tahun 2003 tentang Pedoman Penyusunan Standar Kompetensi Jabatan Struktural Pegawai Negeri Sipil. Badan Kepegawaian Nasional: Jakarta.

Republik Indonesia. 2003b. Undang-Undang Nomor 17 Tahun 2003 tentang Keuangan Negara. 
Sekretariat Negara: Jakarta.

Republik Indonesia. 2003c. Undang-Undang Republik Indonesia Nomor 13 Tahun 2003 tentang Ketenagakerjaan.. Sekretariat Negara: Jakarta.

Republik Indonesia. 2004a. Undang-Undang Nomor 1 Tahun 2004 Tentang Perbendaharaan Negara. Sekretariat Negara: Jakarta.

Republik Indonesia. 2004b. Undang-Undang Nomor 15 Tahun 2004 tentang Pemeriksaan Pengelolaan dan Tanggung Jawab Keuangan Negara. Sekretariat Negara: Jakarta.

Republik Indonesia. 2005. Peraturan Pemerintah Nomor 24 Tahun 2005 tentang Standar Akuntansi Pemerintahan. Kementerian Keuangan: Jakarta.

Republik Indonesia. 2008. Peraturan Pemerintah Nomor 60 Tahun 2008 tentang Sistem Pengendalian Intern Pemerintah. Sekretariat Negara: Jakarta.

Republik Indonesia. 2010. Peraturan Pemerintah Nomor 71 Tahun 2010 tentang Standar Akuntansi Pemerintah. Kementerian Keuangan: Jakarta.

Republik Indonesia. 2015. Peraturan Menteri Keuangan Nomor 223 Tahun 2015 tentang Pelaksanaan Piloting Sistem Akuntansi Keuangan Tingkat Instansi. Kementerian Keuangan: Jakarta.

Romanti, G. N. (2018). Pengaruh Sistem Pengendalian Internal, Pemanfaatan Teknologi Informasi, Kapasitas Sumber Daya Manusia Terhadap Kualitas Laporan Keuangan. Universitas Pasundan: Bandung. (Tidak Dipublikasikan).

Romney \& Steinbart. (2015). Sistem Informasi Akuntansi (Terjemahan oleh Kikin Sakinah Nur Safira dan Novita Puspasari (ed.); 13th ed.). Salemba Empat: Jakarta.

Saleh, C., Islamiy, M. I., Zauhar, S., \& Supriyono, B. (2013). Pengembangan Kompetensi Sumber Daya Aparatur. Universitas Brawijaya: Malang.

Samosir, M., \& Setiyawati, H. (2019). the Effect of Competence of Human Resources and the Use of Information Technology on the Quality of Financial Report With Internal Control System and Organizational Commitment As Moderation Variable. International Journal of Advanced Research, 6(12), 517-525.

Sekaran, U., \& Bougie, R. (2016). Metode Penelitian untuk Bisnis: Pendekatan Pengembangan Keahlian. Salemba Empat: Jakarta.

Setyowati, L., Isthika, W., \& Pratiwi, R. D. (2019). Faktor-faktor yang Mempengaruhi Kualitas Laporan Keuangan Pemerintah Daerah Kota Semarang. Kinerja, 20, 179-191.

Simon, Y., Mahfudnurnajamuddin, Mas'ud, M. \& Su'un, M. (2016). The Role of Apparatus Competence, Internal Control System on Good Governance and the Quality of Financial Statement Information. Researchers World : Journal of Arts, Science and Commerce, 7(4), 123132.

Spencer, L. \& Spencer, S. M. (1993). Competence at Work, Models For Superior Performance. John Wiley \& Sons, Inc: Canada.

Sugiyono. (2017). Metode Penelitian Kuantitatif, Kualitatif, dan R\&D. Alfabeta: Bandung.

Susanto, A. (2013). Sistem Informasi Akuntansi. Lingga Jaya: Bandung.

Synthia. (2017). The Effect of Human Resources Competence and Application of Regional Financial Accounting Systems on Quality of Financial Report. Journal of Applied Accounting and Taxation, $2(1), 68-74$.

Torabi, E., \& Salehi, M. (2012). The Role of Information Technology in Financial Reporting Quality: Iranian Scenario. Poslovna Izvrsnost, 6(1), 127-127.

Upping \& Oliver, J. (2011). Accounting Change Model for The Public Sector: Adopting Luder's Model for Developing Countries. International Review of Business Resarch Papers, 7, 364-380.

Wadiyo. (2020). Pengertian Sistem Pengendalian Internal, Prinsip, Tujuan, Manfaat \& Contoh Penerapan di Perusahaan. https://manajemenkeuangan.net/pengendalian-internal/, diakses 9 Maret 2020.

Wati, L. N. (2018). Metodologi Penelitian Terapan Aplikasi SPSS, Eviews, SmartPLS dan Amos. Pustaka Amri: Jakarta.

Wibowo, A., \& Darmanto, S. (2019). Improvement Quality of Financial Report Model by Good Governance, Utilization of Information Technology and Internal Control. IOSR Journal of Economics and Finance, 10(4), 9-17. 